\title{
GLOSY
}

\section{MIROSŁAW NESTEROWICZ}

\section{Glosa do wyroku Sądu Apelacyjnego w Białymstoku z dnia 9 marca 2016 r., I ACa $817 / 15^{1}$}

1. Do obowiązków lekarzy należy także prawidłowe postępowanie pooperacyjne, zwłaszcza wtedy, gdy podczas zabiegu wystapiły powikłania wymagające dalszych czynności medycznych.

2. Odpłatność czy nieodpłatność zabiegów medycznych nie może mieć wpływu na stopień staranności lekarzy w postępowaniu diagnostycznym, leczniczym i rehabilitacyjnym.

3. Ubezpieczyciel szpitala (lekarza) jako interwenient uboczny w procesie odszkodowawczym, wytoczonym przez pacjenta, może podnosić wszelkie zarzuty, takie, jakie może podnieść pozwany (np. co do błędu sztuki lekarskiej, szkody doznanej przez powoda, przyczynienia się poszkodowanego, wysokości zadośćuczynienia, przedawnienia roszczeń].

\section{GLOSA}

1. Powódka w dniu 3 stycznia 2007 r. zgłosiła się do pozwanej kliniki - niepublicznego zakładu opieki zdrowotnej w celu przeprowadzenia porodu drogą cesarskiego cięcia. Powódka urodziła syna, lecz w czasie zabiegu lekarz ginekolog doprowadził do uszkodzenia (przerwania ciagłości) pęcherza moczowego, skutkiem czego były ostre napady bólowe, zapalenie otrzewnej i konieczność pilnej dodatkowej operacji. Sąd Okręgowy w Ostrołęce na podstawie opinii biegłych przyjał, że lekarz przy eliminowaniu skutków uszkodzenia pęcherza popełnił zawiniony błąd medyczny zszycia pęcherza w sposób jednowarstwowy zamiast szwu dwuwarstwowego, co zwiększyłoby jego skuteczność i zniosłoby ryzyko dalszych powikłań. Ponadto po zszyciu nie sprawdził szczelności pęcherza metodą kontrastu, co dawałoby pewność zweryfikowania zabiegu zszycia. Dodatkowa operacja, której 13 stycznia 2007 r. dokonali chirurg i ginekolog w innym szpitalu, polegała na otworzeniu brzegu rany, oczyszczeniu okolic pęcherza moczowego, dwupiętrowego ponownego zszycia i wypłukania jamy otrzewnej. W szpitalu powódka pozostawała przez 9 dni,

1. LEX nr 2016283. Tezy odautorskie wynikające z uzasadnienia wyroku Sądu Apelacyjnego. 
a po wyjściu jeszcze przez dwa tygodnie przyjmowała leki przeciwbólowe i zastrzyki. Sprawność odzyskała po około trzech miesiącach.

Pozwani klinika i lekarz ginekolog twierdzili, że przerwanie ściany pęcherza moczowego w trakcie cesarskiego cięcia jest jednym z typowych powikłań tego typu zabiegów i choć dość rzadkie (0,08 - 0,94\%), to się zdarza, i wnosili o oddalenie powództwa. Zdaniem Sądu Okręgowego nie przesądza to samo w sobie o braku odpowiedzialności pozwanych. Przewidywalność wystapienia powikłań przemawia natomiast za wzmożona procedurą ostrożnościową po stronie lekarza, a także za założeniem szwu dwuwarstwowego, sprawdzeniem szczelności pęcherza najpewniejszą metodą i wnikliwym monitorowaniem zdrowia pacjentki, czego nie dopełniono.

Biegli wskazali również, że wạtpliwości budzi postępowanie pooperacyjne pozwanego lekarza ginekologa związane ze zbyt krótkim utrzymaniem cewnika moczowego - 4 dni zamiast 10-14. Usunięcie cewnika powoduje bowiem napór moczu na ściany pęcherza, prowadząc do niepożądanych i bolesnych naprężeń. Lekarz powinien więc rozważyć dłuższe utrzymywanie cewnika celem stworzenia dogodnych warunków do wytworzenia się zrostu. Cewnik został jednak usunięty na żądanie powódki ze względu na jej dolegliwości bólowe i dyskomfort. Winą lekarza było natomiast niepoinformowanie powódki o zagrożeniach wynikających z braku cewnika, tj. możliwości rozejścia się miejsca uszkodzenia pęcherza moczowego i konieczność ponownej operacji. Sąd stwierdził, że w przypadku udzielenia takiej informacji z dużym prawdopodobieństwem można założyć, iż powódka nie zażądałaby wcześniejszego usunięcia cewnika.

W orzecznictwie nieraz podkreślano, że obowiązki lekarza nie kończą się z chwilą dokonania zabiegu, gdyż pacjent powinien być objęty nadzorem pooperacyjnym, zwłaszcza wtedy, gdy podczas zabiegu wystapiły komplikacje, wymagające dalszych czynności medycznych (badań, kolejnych zabiegów operacyjnych, rehabilitacji], co pozwoliłoby uniknąć szkody albo przynajmniej zmniejszyć jej rozmiar. Pacjent wyrażając zgodę na zabieg, bierze na siebie ryzyko zwykłych powikłań pooperacyjnych, o których został poinformowany, pod warunkiem, że nie zostaną one spowodowane z winy, choćby najlżejszej, lekarza².

2. Ponieważ powódka zwróciła się do niepublicznego zakładu leczniczego, w którym za czynności medyczne związane z porodem zapłaciła, to w procesie powstał problem stopnia staranności lekarza jako oceny jego winy, skoro czynności były odpłatne. Sąd Okręgowy orzekł, że „powódka decydując się na odpłatną opiekę w zakładzie niepublicznym, miała prawo domagać się najwyższej staranności i nowoczesności w wyborze metody przez lekarza operującego” oraz że „pacjent decydujący się na skorzystanie z odpłatnej opieki medycznej powinien otrzymać ekwiwalent najwyższej jakości i staranności w realizacji wzorca dobrego lekarza, a w okolicznościach sprawy tak się nie stało". Sąd Apelacyjny rozumowanie to odrzucił, stwierdzając, że: „... nie uzasadnia tego fakt, że leczenie powódki było odpłatne, a zatem zobowiązujące lekarza, zdaniem Sądu Okręgowego, do najwyższej staranności i nowoczesności w wyborze metody przez lekarza operującego. Wniosek taki nie ma podstaw w obowiązujących przepisach prawa".

Stanowisko Sądu Apelacyjnego jest trafne. Staranność lekarza, do której jest zobowiązany, wynika z zasad wiedzy i praktyki lekarskiej, przepisów prawa i Kodeksu Etyki Lekarskiej, ustalonych standardów

2. Zob. orzecz. SN z 18 I 2013 r., IV CSK 431/12. LEX nr 1275006; orzecz. SA w Lublinie z 4 III 2009 r., I ACa 12/09, PiM 2/2011, z glosą M Nesterowicza; orzecz. SA w Warszawie z 24 I 2008 r., I ACa 354/07, PS 9/2010, z glosa M. Nesterowicza; orzecz. SN z 29 X 2003 r., III 34/02, OSP 4/2005, poz. 54, z glosą E. Bagińskiej. 
diagnostyki i leczenia jako minimum postępowania - stosowanie się do nich nie wystarczy, jeżeli w danych okolicznościach lekarz mógł i powinien zrobić więcej, specjalizacji, obowiązku dokształcania się itp. ${ }^{3}$ Sąd Apelacyjny w Lublinie w wyroku z 29 września 2005 r. (I ACa 510/05, PiM 3/2006, z glosą M. Nesterowicza] stwierdził, że do obowiązków lekarza oraz personelu medycznego należy podjęcie takiego sposobu postępowania (leczenia), które gwarantować powinno, przy zachowaniu aktualnego stanu wiedzy i zasad staranności, przewidywalny efekt w postaci wyleczenia, a przede wszystkim nienarażanie pacjentów na pogorszenie stanu zdrowia. Podobnie orzekł Sạd Najwyższy w wyroku z 10 lutego 2010 r. (V CSK 287/09, PiM 3-4/2012, z glosą M. Nesterowicza). Przy wzięciu pod uwagę powyższych okoliczności sądy na ogół wymagają od lekarzy staranności przeciętnej dostosowanej do obiektywnego i abstrakcyjnego wzorca (wyrok Sądu Apelacyjnego w Łodzi z 22 grudnia 2014 r., I ACa 903/14, LEX nr 1659104 - uzasadn.). Na staranność w postępowaniu lekarza nie może wpływać charakter stosunków prawnych lekarza (szpitala) z pacjentem i fakt, czy leczenie było odpłatne czy nieodpłatne. Na postępowanie to moga natomiast wpływać okoliczności zabiegu (zwłaszcza nagłość zabiegu, usprawiedliwiona niemożność skontaktowania się ze specjalistą, możliwości diagnostyczne szpitala ze względu na posiadany sprzęt medyczny itp.).

W polskiej rzeczywistości leczenie nieodpłatne występuje rzadko. Odpłatne jest w prywatnych szpitalach, klinikach, gabinetach lekarskich, a także w szpitalach należących do publicznej służby zdrowia, bo tam za leczenie ubezpieczonego pacjenta (który płaci składkę) płaci Narodowy Fundusz Zdrowia ${ }^{4}$. Fundusz powinien również pokryć szpitalom koszty świadczeń zdrowotnych udzielonych w sytuacji zagrożenia życia lub zdrowia osobom nieposiadającym uprawnień z tytułu ubezpieczenia zdrowotnego (wyrok Sądu Najwyższego z 8 VIII 2007 r., I CSK 125/07, 0SP 7-8/2008, poz. 72, z glosa M. Nesterowicza], choć nie zawsze to czyni, stąd procesy szpitali wobec Funduszu przed sadami.

Leczenie całkowicie lub częściowo nieodpłatne prowadzą niektóre hospicja (jeśli nie są finansowane przez Fundusz] oraz lekarze świadczący usługi charytatywnie. Art. 66 ust. 3 KEL przewiduje, że „lekarz może leczyć bezpłatnie”, a art. 67, że: „Dobrym zwyczajem jest leczenie bezpłatne lekarzy i członków ich najbliższej rodziny, w tym wdów wdowców i sierot po lekarzach”. Choć Polska to nie jest kraj dla Judymów. Jeśli lekarz chciałby w swoim prywatnym gabinecie leczyć bezpłatnie ubogich, to i tak Fiscus każe mu zapłacić podatek od wartości świadczenia.

Odpłatność czy nieodpłatność zabiegów medycznych nie powinna mieć więc żadnego wpływu na staranność lekarza w leczeniu. Jest to jeden z nielicznych przypadków, gdy nieodpłatność czynności nie będzie prowadzić do oceny postępowania sprawcy szkody według diligentia quam suis. Taki poglaad można spotkać w literaturze obcej, zwłaszcza anglosaskiej ${ }^{5}$, i polskiej ${ }^{6}$.

3. Por. M. Nesterowicz, Prawo medyczne, wyd. XI, Toruń 2016, s. 96 i n.

4. Dotyczy to określonych w rozporządzeniach MinistraZdrowia świadczeń gwarantowanych, o których mowa w art. 15 ust. 2 ustawy o świadczeniach opieki zdrowotnej finansowanych ze środków publicznych [t.j. Dz.U. z 2018 r., poz. 1510 z późn. zm.) finansowanych w całości lub współfinansowanych ze środków publicznych na zasadach określonych w cyt. ustawie [tzw. „koszyk pozytywny świadczeń”). Inne propozycje jak dotąd nie zostały zaakceptowane.

5. Zob. B. Shartel, M.L. Plant, The Law of Medical Practice, Springfield (Illinois) 1959, s. 117; P.C. Nathan, Medical Negligence, Londyn 1957, s. 34; C.A. Wright, Cases on the Law of Torts, 3. wyd., Londyn 1963, s. 814; W.L. Prosser, Handbook of the Law of Torts, St. Paul 1955, s. 133.

6. M. Sośniak, Cywilna odpowiedzialność lekarza, Warszawa 1968, s. 131; W. Ludwiczak, Umowa zlecenia, Poznań 1955, s. 95, który w związku z odpowiedzialnością kontraktową lekarza pisał: „Dający zlecenie, powierzając bezpłatnie wykonanie czynności przyjmującemu zlecenie, liczy na jego staranność i fachowość i tylko w zaufaniu do tych czynników powierza wykonanie czynności określonej osobie”. 
Oczywiście odpłatność może wpływać niekiedy na szerszy zakres i wyższy poziom świadczeń leczniczych, hospitalizacyjnych czy rehabilitacyjnych, np. znieczulenie przy porodzie (dawniej nierefundowane przez NFZ), lepsze i bardziej trwałe materiały stosowane przez lekarzy dentystów (np. plomby czy implanty nieobjęte finansowaniem przez NFZ) czy aparaty ortopedyczne dla niepełnosprawnych (częściowo refundowane przez NFZ), dodatkową pomoc świadczoną chorym przez „prywatne” pielęgniarki, lepsze warunki hospitalizacji w prywatnych klinikach i szpitalach itp.

Podstawowy standard świadczeń leczniczych musi być jednak wszędzie zachowany? odpowiednio wyższy w specjalistycznych klinikach i szpitalach mających wyższy poziom referencyjny. Pacjent ma prawo wówczas oczekiwać większej wiedzy i kompetencji lekarzy, bardziej wyspecjalizowanej i pogłębionej diagnostyki oraz wyższego poziomu leczenia i opieki. Wówczas będzie także wyższy obiektywny i abstrakcyjny wzorzec staranności lekarza. Świadczeniodawca jest zobowiązany udzielać świadczeń pacjentom z zachowaniem należytej staranności i jakości świadczeń zgodnie z przepisami prawa oraz ze wskazaniami aktualnej wiedzy medycznej, dostępnymi metodami i środkami zapobiegania, rozpoznawania i leczenia chorób oraz zgodnie z zasadami etyki zawodowej, jak również do przestrzegania ich praw (zob. też rozporzadzenie Ministra Zdrowia z 8 września 2015 r. w sprawie ogólnych warunków umów o udzielanie świadczeń opieki zdrowotnej, Dz.U. z 2016 r., poz. 1146].

Dla porównania warto wskazać na sytuację w USA, gdzie są najwyższe na świecie ceny za usługi medyczne, a miliony ludzi jest nieubezpieczonych (stąd tak ważna jest ustawa Obamacare, która pozwoliła objąć ochroną ubezpieczeniowa ponad $20 \mathrm{mln}$ ludzi). Nie oznacza to jednak, że ciężko chory, nieubezpieczony, zostanie „na ulicy” i żaden szpital nie udzieli mu pomocy. Przede wszystkim najbiedniejsi są objęci opieką medyczną w ramach rządowego programu Medicaid. Poza tym jest wiele szpitali publicznych (należących do państwa i finansowanych w zależności od szczebla władzy - federalne, stanowe, miejskie, okręgowe, lokalne) i prywatnych (należących do kościołów, organizacji prowadzących działalność charytatywna, różnych społeczności] mających przeważnie charakter fundacji - Non Profit Hospitals, Private Charitable Hospitals, Voluntary Hospitals, gdzie pacjenci w zależności od zamożności pokrywaja całość lub część kosztów leczenia albo leczeni są za darmo. Pacjent przychodzący do takiego szpitala musi liczyć się z tym, że nie będzie tam wybitnych specjalistów ani najnowocześniejszego sprzętu medycznego, czasami otrzyma tylko podstawowa pomoc, lecz lekarze muszą zawsze dokładać należytej staranności. Począwszy od XIX w. szpitale charytatywne miały immunitety (ustalone w drodze orzeczeń sądowych lub ustaw) wyłaczające lub ograniczające ich odpowiedzialność za szkodę (w razie szkody pacjent miał bezpośrednie roszczenie tylko do lekarzy lub personelu medycznego), lecz w ostatnich kilkudziesięciu latach immunitety takie są coraz bardziej ograniczane i osłabiane ${ }^{8}$.

3. Sąd Okręgowy przyjmując, że za uszkodzenie pęcherza, dolegliwości bólowe, których doznała powódka i konieczność dodatkowej operacji, odpowiedzialność ponoszą pozwani, zasądził na jej rzecz zadośćuczynienie w kwocie 40.000 zł (zamiast żądanej kwoty 120.000 zł, którą sąd ocenił jako wygórowana]. Uznał, że jest to kwota adekwatna do krzywdy, zwłaszcza, że powódka jest już

7. W przeciwnym razie można mówić o winie lekarza lub zakładu leczniczego - por. B. Lewaszkiewicz-Petrykowska, Wina lekarza i zakładu opieki zdrowotnej jako przesłanka odpowiedzialności cywilnej za szkody wyrządzone przy leczeniu, PiM 1/1999, s. 124 i n.

8. Zob. M. Nesterowicz, Prawo cywilne USA, Toruń 1999, s. 151 i n. 
całkowicie i trwale wyleczona i nie ma trwałego uszczerbku na zdrowiu. Kwota ta powinna rekompensować doznane przez powódkę cierpienia. Pozwani (oraz po stronie pozwanej ubezpieczyciel jako interwenient uboczny ${ }^{9}$ ] kwestionowali popełnienie przez lekarza błędu sztuki lekarskiej i zadośćuczynienie jako zawyżone. Apelacje ich (w których wnosili o zmianę zaskarżonego wyroku i oddalenie powództwa w całości, ewentualnie o uchylenie zaskarżonego wyroku w całości i przekazanie sprawy do ponownego rozpoznania] Sąd Apelacyjny oddalił jako bezzasadne. Podzielił ustalenia dokonane przez Sąd Okręgowy i stwierdził: „Sam fakt wskazywany w apelacji interwenienta [ubezpieczyciela - przyp. M.N.] braku trwałych negatywnych skutków doznanej szkody na osobie, nie może decydować o uznaniu przyznanego zadośćuczynienia za zawyżone. Życie powódki było zagrożone z uwagi na wyciek moczu do jamy otrzewnej, nadto powódka przebyła ponowny zabieg chirurgiczny”. Dodał, że „Ingerencja sądu odwoławczego jest uzasadniona, gdy przyznana kwota jest rażąco wygórowana lub zaniżona ${ }^{10}$. Taka sytuacja w sprawie nie zachodzi”.

PROF. DR HAB. MIROSŁAW NESTEROWICZ - Uniwersytet Mikołaja Kopernika w Toruniu

9. Interwenient uboczny w procesie odszkodowawczym, wytoczonym przez pacjenta, może podnosić wszelkie zarzuty, jakie może podnieść pozwany (art. 79 k.p.c.). Ponieważ w procesie chroni własny interes prawny, ustawodawca wyposażył go w szerokie kompetencje w zakresie dokonywania czynności procesowych. Nie może jednak zawrzeć ugody, uznać roszczenia, zrzec się roszczenia, zniweczyć skutków czynności procesowej strony czy dokonać czynności procesowej sprzecznej z wolą strony. Takie czynności interwenienta nie wywierają skutków prawnych (uchwała SN z 25 VIII 1989 r., III CZP 75/89, Legalis) - zob. Kodeks postępowania cywilnego. Komentarz 2017 (red. A. Zieliński, K. Flaga-Gieruszyńska), wyd. 9, Legalis; Kodeks postępowania cywilnego. Komentarz 2018 (red. E. Marszałkowska-Krześ), wyd. 22, Legalis; Kodeks postępowania cywilnego. Tom I. Komentarz (red. A. Marciniak, K. Piasecki), wyd. ?, 2016, Legalis.

10. Jest to zgodne z ustalonym stanowiskiem Sądu Najwyższego - zob. wyroki SN z 15 IX 1999 r., III CKN 330/98, OSP 4/2000, poz. 66; z 29 IX 2000 r., V CKN 527/00, OSN 1/2001, poz. 42 - uzasadn.; z 20 IV 2006 r., IV CSK 99/05, 0SP 4/2009, poz. 40, z glosą M. Nesterowicza. 
